\title{
Contrasting Responses in the Niches of Two Coral Reef Herbivores Along a Gradient of Habitat Disturbance in the Spermonde Archipelago, Indonesia
}

\section{OPEN ACCESS}

Edited by:

Alberto Basset,

University of Salento, Italy

Reviewed by:

Nafsika Papageorgiou,

Hellenic Centre for Marine Research,

Greece

Charlotte Dromard

Univesité des Antilles, Guadeloupe

*Correspondence: Jeremiah G. Plass-Johnson

jplass@uni-bremen.de

${ }^{\dagger}$ Present Address:

Jeremiah G. Plass-Johnson,

Centre for Ocean Life, Technical University of Denmark, Charlottenlund,

Denmark

Vanessa N. Bednarz,

Marine Department, Centre Scientifique de Monaco, Monaco,

Monaco

Specialty section: This article was submitted to Marine Ecosystem Ecology, a section of the journal Frontiers in Marine Science

Received: 14 December 2016 Accepted: 24 January 2018

Published: 16 February 2018

Citation:

Plass-Johnson JG, Bednarz VN Hill JM, Jompa J, Ferse SCA and

Teichberg M (2018) Contrasting Responses in the Niches of Two Coral Reef Herbivores Along a Gradient of Habitat Disturbance in the Spermonde

Archipelago, Indonesia.

Front. Mar. Sci. 5:32.

doi: 10.3389/fmars.2018.00032

\author{
Jeremiah G. Plass-Johnson ${ }^{1,2 \star t}$, Vanessa N. Bednarz ${ }^{1,2+}$, Jaclyn M. Hill ${ }^{3,4}$, \\ Jamaluddin Jompa ${ }^{5}$, Sebastian C. A. Ferse ${ }^{1,2}$ and Mirta Teichberg ${ }^{1}$ \\ ${ }^{1}$ Leibniz Centre for Tropical Marine Research, Bremen, Germany, ${ }^{2}$ Faculty of Biology and Chemistry, University of Bremen, \\ Bremen, Germany, ${ }^{3}$ South African Institute of Aquatic Biodiversity (SAIAB), Grahamstown, South Africa, ${ }^{4}$ Fisheries and \\ Oceans Canada, Institut Maurice-Lamontagne, Mont-Joli, QC, Canada, ${ }^{5}$ Center for Marine, Coastal and Small Islands \\ Research, Hasanuddin University, Makassar, Indonesia
}

Habitat modification of coral reefs is becoming increasingly common due to increases in coastal urban populations. Coral reef fish are highly dependent on benthic habitat; however, information on species-specific responses to habitat change, in particular with regard to trophic strategies, remains scarce. This study identifies variation in the trophic niches of two herbivorous coral reef fishes with contrasting trophic strategies, using Stable Isotopes Bayesian Ellipses in R, along a spatial gradient of changing coral reef habitats. In the parrotfish Chlorurus bleekeri, a roving consumer, the range of $\delta^{15} \mathrm{~N}$ and $\delta^{13} \mathrm{C}$ and their niche area displayed significant relationships with the amount of rubble in the habitat. In contrast, the farming damselfish, Dischistodus prosopotaenia, showed a narrow range of both $\delta^{15} \mathrm{~N}$ and $\delta^{13} \mathrm{C}$, displaying little change in niche parameters among sites. This may indicate that parrotfish vary their feeding according to habitat, while the damselfish continue to maintain their turf and invertebrate resources. Assessing isotopic niches may help to better understand the specific trophic responses to change in the environment. Furthermore, the use of isotopic niches underlines the utility of stable isotopes in studying the potential impacts of environmental change on feeding ecology.

Keywords: isotopic niche, $\delta^{13} \mathrm{C}, \delta^{15} \mathrm{~N}$, Spermonde Archipelago, coral triangle, Makassar, disturbance

\section{INTRODUCTION}

The effects of terrestrially-derived disturbance gradients in marine waters across coral reefs have been noted from many parts of the world (Edinger et al., 1998; Mallela et al., 2004; Fabricius et al., 2005; Lirman and Fong, 2007; Teichberg et al., 2018). Coral reefs closer to shore are generally characterized by less hard coral abundance, an increase in fleshy algae, a general loss of habitat complexity, and by a decrease in coral and fish species diversity or even complete shifts in the sets of species (Fabricius et al., 2005; Plass-Johnson et al., 2015a, 2018). Anthropogenic impacts can alter the resource availability and predator-prey relationships on a coral reef thus affecting habitat use and the trophic niche of the biotic constituents (Jones and Syms, 1998; Syms and Jones, 2000). Thus, changes in coral reef communities along disturbance gradients may be associated 
with a change in their trophic structure (Jennings et al., 1995). However, the trophic structure of coral reef communities is highly complex, and discerning the specific change of habitat use of any individual species can be challenging due to the high biological diversity on reefs (Fenner, 2012). Nevertheless, revealing trophodynamics of a coral reef community may allow for better interpretation of community change under varying environmental stress (Done, 1992) and help facilitate management decisions that break negative feedback loops (Glaser et al., 2018).

The trophic niche of an organism has been described as the bionomic portion of a specie's ecological niche, divisible to $n$ dimensions based on the sum of all nutritional resource use (Hutchinson, 1978). Stable isotope ratios of a consumer are closely linked to their diet (Post, 2002) and thus are similar to the bionomic niche axis. The heavier stable nitrogen $\left({ }^{15} \mathrm{~N}\right)$ and stable carbon $\left({ }^{13} \mathrm{C}\right)$ isotopes accrue in consumers with an increase in trophic level (Post, 2002). The isotopic structure of a system depends on the availability of dissolved inorganic nitrogen (DIN) and carbon (DIC) and its use by the system's primary producers (Post, 2002) which can then be reflected at higher trophic levels (Harvey and Kitchell, 2000; Post, 2002; Letourneur et al., 2013). As a result of environmental heterogeneity, seasonality and differences in physiology, primary producers may exhibit variability in isotopic signatures over space and time (Dethier et al., 2013) both within and among species. However, as long as this isotopic variability in the prey items is lower than variance resulting from dietary shifts of their consumers, which can be revealed by sampling of prey items, variance in isotopic signature of the consumers is assumed to be a robust measure of trophic niche width (Bearhop et al., 2004). Recently, multivariate, Bayesian techniques have utilized $\delta^{15} \mathrm{~N}$ and $\delta^{13} \mathrm{C}$ data to describe the niche width of community members (Bearhop et al., 2004; Newsome et al., 2007; Jackson et al., 2011; Dromard et al., 2013).

Herbivorous fishes can remove excess macrophyte growth that might compete with corals for space and light resources (Bellwood et al., 2006; Hughes et al., 2007; Bonaldo et al., 2014), representing a group of interest with respect to variation in trophodynamics. However, herbivores are diverse in their feeding strategies, with resource preferences varying between erect macroalgae and turf algae (Choat et al., 2002, 2004). Turf algae is recognized as a potential impediment to coral reef development (Jompa and McCook, 2003; Vermeij et al., 2010; Smith et al., 2016; Ford et al., 2018) and thus, understanding how the trophic strategy of turf algae consumers responds to changing environments is important to elucidate the potential implications of environmental change for trophodynamics in reefs.

This study explores variation in the trophic niche space of two consumers of turf algae (Bay, 1999; Ledlie et al., 2007) with different trophic strategies. Individuals of the parrotfish, Chlorurus bleekeri (de Beaufort, 1940), and the farming damselfish, Dischistodus prosopotaenia (Bleeker, 1852), were collected at islands of the Spermonde Archipelago, Indonesia, representing a spatial gradient away from the urban center of Makassar. These reefs have documented variation in habitat composition with relation to disturbance (Edinger et al., 1998; Cleary and Renema, 2007), with low live coral cover and high amounts of coral rubble with increasing turf algae recruitment and abundance (Plass-Johnson et al., 2016a) at the near-shore, impacted reefs. C. bleekeri and D. prosopotaenia were both observed to persist at most of the reefs, potentially reflecting trophic variation associated with habitat structure. Species of parrotfish in the same genus as C. bleekeri have been shown to forage up to $130 \mathrm{~m}$ for food resources (Welsh and Bellwood, 2012) while $D$. prosopotaenia, a farming damselfish, continuously maintains a patch of turf algae approximately one square meter in size (Hoey and Bellwood, 2010). Both fish consume turf algae but recent work suggests that parrotfishes may not be directly targeting this source for their diet (Clements et al., 2016). The goal of the current study is not to reconstruct the diets of the two fishes, but rather to identify changes in their trophic niche, identified through stable isotopes, in association with changes in their environment. Therefore, this study examines the variation of the trophic niches of the two herbivorous fish species across an environmental gradient, assuming that variation in habitat degradation may alter their trophic niche space through modification of available benthic food items; however, it is assumed that variation in the isotopic niche will be greater in $C$. bleekeri than D. prosopotaenia due to the latter's predisposition to self-maintain its nutritional resources.

\section{MATERIALS AND METHODS Study Site Description}

This study was conducted in November 2014, at six islands of the Spermonde Archipelago, Indonesia varying in distance from the city of Makassar (Figure 1). Samalona (SA; $05^{\circ} 07^{\prime} \mathrm{S}, 119^{\circ} 20^{\prime} \mathrm{E}$, $7 \mathrm{~km}$ distance) was the closest site to the mainland, followed by Barrang Lompo (BL; $05^{\circ} 02^{\prime} \mathrm{S}, 119^{\circ} 19^{\prime} \mathrm{E}, 11 \mathrm{~km}$ distance), Bonetambung (BO; $05^{\circ} 01^{\prime} \mathrm{S}, 119^{\circ} 16^{\prime} \mathrm{E}, 14 \mathrm{~km}$ distance), Badi (BA; $04^{\circ} 57^{\prime} \mathrm{S}, 119^{\circ} 16^{\prime} \mathrm{E}, 19 \mathrm{~km}$ distance), Karang Kassi (KS; $04^{\circ} 53^{\prime} \mathrm{S}, 119^{\circ} 09^{\prime} \mathrm{E}, 27 \mathrm{~km}$ distance) and Kapoposang (KP; $04^{\circ} 41^{\prime} \mathrm{S}, \quad 118^{\circ} 57^{\prime} \mathrm{E}, \quad 55 \mathrm{~km}$ distance; Figure 1). November represents the end of a 4-month dry season, thus minimizing small-scale, temporal variation of nutrient inputs available to primary producers in each community. The benthic community assessment and the fish and algal collections were conducted at the northwest corner of each island to standardize the sampling sites among reefs, except for KP. The western side of the islands generally features a well-developed, carbonate fore-reef and a sandy back-reef and flat. The reef crest is shallow $(\sim 3 \mathrm{~m})$ and the slope reaches down to $15 \mathrm{~m}$. The last study site, $\mathrm{KP}$, is located on the outer shelf wall of the archipelago and is exposed to deep oceanic waters, contributing to well-developed coral reefs with high biodiversity. Work at KP was conducted at the northeast side of the island at the edge of the carbonate shelf, which was more consistent with the structural conditions at the other sites.

\section{Benthic Community Assessment}

Benthic communities were quantified in parallel with Teichberg et al. (2018) and Plass-Johnson et al. (2018). At each island there were 50 photographic quadrats per $50 \mathrm{~m}$ transect. Three replicate transects were assessed per site at $5 \mathrm{~m}$ depth, $2 \mathrm{~m}$ below 


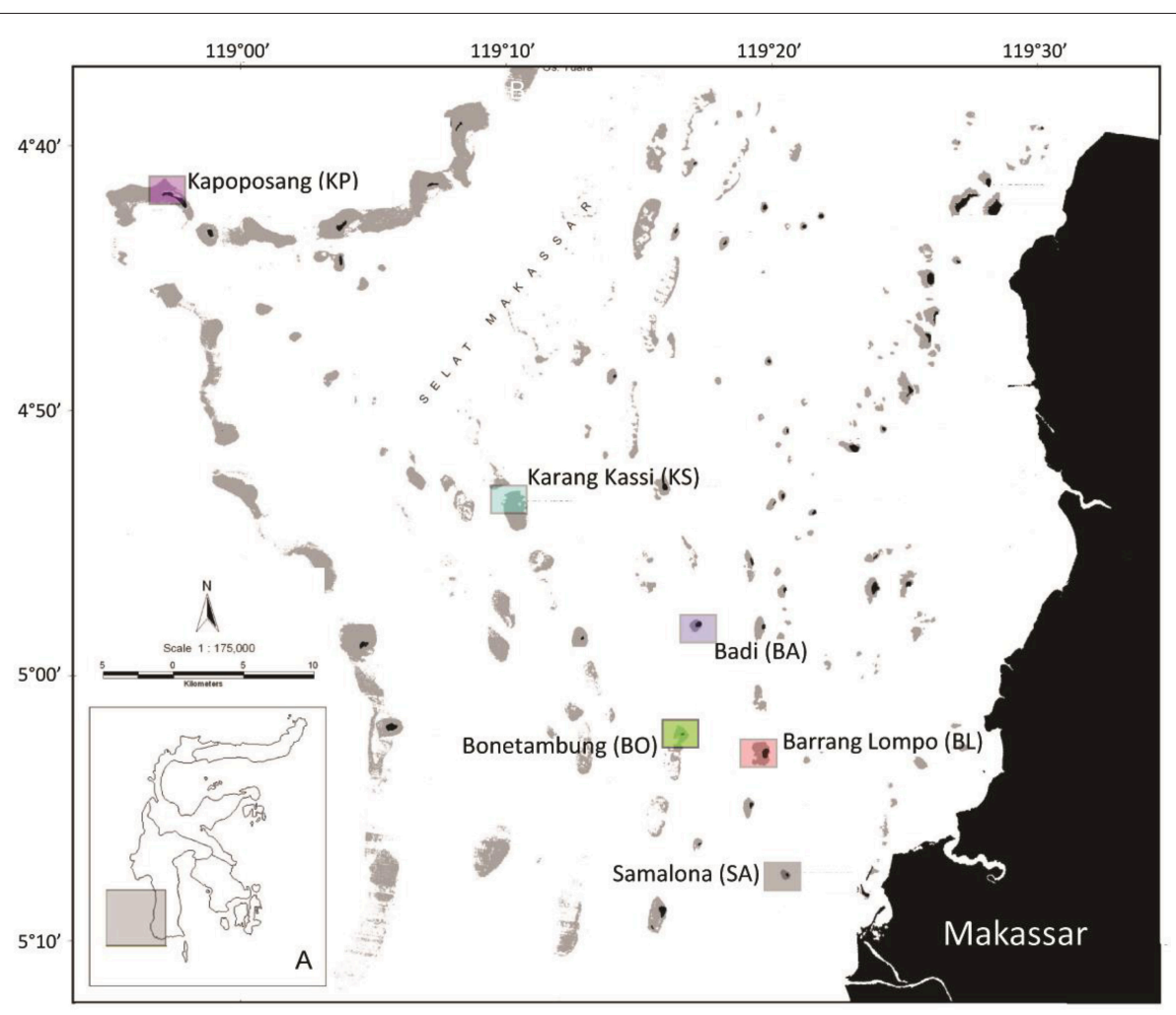

FIGURE 1 | Map of the Spermonde Archipelago with inset (A) indicating the islands' location in reference to Sulawesi, Indonesia. Squares indicate the sampling sites and the in-text acronym is given in parentheses. Colors correspond with Figures 5, 6.

the reef crest, because this represented a common habitat for both of the sampled species of fish. Photographs were taken at $1 \mathrm{~m}$ (standardized with a measuring pole) above the substratum, every $2 \mathrm{~m}$ along each transect. A photograph was taken on both sides of the transect tape, with a section of the tape within the photo to identify total area of the photograph. Analysis of the photographs was conducted with Coral Point Count with Excel extensions (CPCe; Kohler and Gill, 2006) using fifty randomized points per photograph for complementary descriptors of structure and biotic groups (Brown et al., 2004). The biotic groups included: ascidians, sponges, soft corals, crustose coralline algae (CCA), other invertebrates, cyanobacteria, macroalgae, turf algae, and live hard coral; however groups with $<1 \%$ of total cover were dropped from subsequent analysis assuming that fishes' dietary and behavioral changes would largely be a product of the most abundant benthic groups. The selection of benthic categories was based on English et al. (1997). Biotic groups comprised any epi-growth irrespective of the surface structure type. To complement this, physical surface structure was also identified. Structural groups were categorized as being comprised of sand, rubble or pavement (defined as any flat, low-relief or sloping solid benthic space). Rugosity was the third measurement of the benthic habitat, and this was assessed with the linear distance-fitted chain method (Risk, 1972). The chain length used was $20 \mathrm{~m}$, and measurement was conducted once per transect, starting at the first $10 \mathrm{~m}$ point.

\section{Fish and Benthic Collection}

A total of 64 Chlorurus bleekeri and 44 Dischistodus prosopotaenia were collected with a speargun using SCUBA. The collection was conducted at each island within a $200 \mathrm{~m}$ long strip, within the area described by benthic surveys, between 3 and $15 \mathrm{~m}$ water depth. After returning to the field lab (greatest travel time $2 \mathrm{~h}$ ), dorsal white muscle tissue was sampled from each fish and dried at $60^{\circ} \mathrm{C}$ for $48 \mathrm{~h}$. D. prosopotaenia was not present at, and therefore not sampled from, KP.

To identify variation in $\delta^{15} \mathrm{~N}$ and $\delta^{13} \mathrm{C}$ of three different representative food items of the two fish species (Bay, 1999; Choat et al., 2002, 2004; Hoey and Bellwood, 2010), the brown calcifying algae Padina sp., filamentous turf algae and a mix of detritus (with the associated microphytobenthos) within the sediment were collected within the $200 \mathrm{~m}$ strip of reef coinciding with fish collection. It should be noted that samples of Padina sp. were also used as indicators of environmental condition within Teichberg et al. (2018). Collection depth was always $5 \mathrm{~m}$ below low tide to standardize light-associated change in plant isotopic values. Five replicates each of Padina, turf algae and detritus were collected along each of the transects. Individual strands of turf algae were isolated from pieces of rubble collected from outside of damselfish territories. All algal samples were cleaned of detritus and epiphytes, rinsed with distilled water, and then dried in a similar fashion to fish muscle tissue. Detritus samples for stable isotope analysis were taken from the top $2 \mathrm{~mm}$ of the 
sediment using $2.0 \mathrm{ml}$ Eppendorf tubes. Sediment samples were not collected from BL and KS due to logistical difficulties.

Fish and algae samples for stable isotope analysis were oven dried $\left(50^{\circ} \mathrm{C}\right.$ for $\left.48 \mathrm{~h}\right)$ and ground to a homogenous powder with mortar and pestle. Subsamples of Padina sp., turf algae and sediment were treated with hydrochloric acid and rinsed with deionized water for analysis of organic $\delta^{13} \mathrm{C}$, and the remaining untreated sample was used for $\delta^{15} \mathrm{~N}$ (Risk et al., 2009). Samples were analyzed for stable isotopic ratios of carbon $\left({ }^{13} \mathrm{C} /{ }^{12} \mathrm{C}\right)$ and nitrogen $\left({ }^{15} \mathrm{~N} /{ }^{14} \mathrm{~N}\right)$ using a Thermo Finnigan Delta Plus mass spectrometer coupled with a Flash EA 112 elemental analyzer at the Leibniz Centre for Tropical Marine Research (Bremen, Germany). Results are expressed in standard $\delta$ unit notation as:

$$
\delta X(\%)=\left[\left(R_{\text {sample }} / R_{\text {reference }}\right)-1\right] \times 1000,
$$

where $\mathrm{X}$ is ${ }^{13} \mathrm{C}$ or ${ }^{15} \mathrm{~N}$, and $R$ is the ratio of ${ }^{13} \mathrm{C} /{ }^{12} \mathrm{C}$ for carbon and ${ }^{15} \mathrm{~N} /{ }^{14} \mathrm{~N}$ for nitrogen. The analytical precision of the measurement was $<0.06 \%$ for both carbon and nitrogen. All $\delta^{13} \mathrm{C}$ and $\delta^{15} \mathrm{~N}$ values were reported as \%o vs. Vienna PeeDeeBelemnite (VPDB) and air, respectively, and normalized to the internal standards of wheat flour (carbon $\left[\delta^{13} \mathrm{C}\right]$; $-27.21 \%$ ) and atmospheric nitrogen (nitrogen $\left[\delta^{15} \mathrm{~N}\right] ; 2.85 \%$ ), and calibrated to the International Atomic Energy reference materials of IAEN N1 and N2 (nitrogen) and USGS 24 and NBS 22 (carbon).

\section{Data Analysis}

Benthic habitat characteristics (biotic composition, structure and rugosity) were square root transformed and analyzed with principle component analysis (PCA) to identify differences among sites. To determine the within-site trophic niches of $C$. bleekeri and $D$. prosopotaenia, their $\delta^{15} \mathrm{~N}$ and $\delta^{13} \mathrm{C}$ values were evaluated with SIBER (Stable Isotope Bayesian Ellipses in R; Jackson et al., 2011) from the SIAR (Stable Isotope Analysis in R; Parnell and Jackson, 2013) package in R (R Core Team, 2015). SIBER was supported with further quantitative population metrics (Layman et al., 2007) for each species, allowing for a comparison of trophic structure among sites. Metrics included nitrogen $(\delta \mathrm{NR})$ and carbon $(\delta \mathrm{CR})$ ranges detailing the total range of nitrogen and carbon values of exploited sources; mean distance to the centroid $(\mathrm{CD})$, providing a description of trophic diversity; standard deviation of nearest neighbor distance (SDNND), which provides a measure of trophic evenness; and standard ellipse area (SEA), which provides a bivariate measure of the core isotopic niche (Layman et al., 2007; Jackson et al., 2011). The calculation of SEA allows for subsequent analysis of the degree of niche overlap (\%) which can then be used as a quantitative measure of dietary similarity among sites (Jackson et al., 2012; Jackson and Britton, 2013). A small sample size correction $\left(S E A_{C}\right)$ for improving accuracy of SEA values was applied as suggested in Jackson et al. (2011). All metrics,

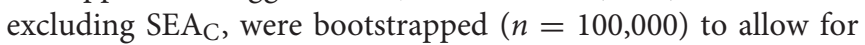
comparisons among sites (Jackson et al., 2011). Layman's metrics were plotted against benthic categories to explore fish trophicbenthic relationships. Significant linear relationships were based on Pearson Product-Moment Correlation Coefficients for the applicable degrees of freedom $(d f=\mathrm{n}-2)$. Furthermore, differences among sites in fish isotope values were determined with permutational analysis of variance (PERMANOVA) with Primer (v7) + PERMANOVA software. Pair-wise comparisons were performed with 9999 permutations based on a Euclidean distance matrix. PERMANOVA was selected because it is robust in instances of uneven sample sizes and when variance is heterogeneous (Anderson et al., 2008).

Each individual food was tested for differences in isotopic values among sites with one-way analysis of variance (ANOVA). In addition, Levene's test was applied to identify significant differences in the variance of isotopic values among sites. ANOVA and Levene's tests were performed with the base package of $\mathrm{R}$.

\section{Ethics Statement}

This research was completed in Indonesian waters in accordance with permits issued by the Indonesian Ministry of Science and Technology (Kementerian Riset dan Teknologi, permit number: 3544/FRP/SM/X/2014). All work was reviewed and approved within the code of conduct for animal ethics of the Leibniz Centre for Tropical Marine Research, Germany, and the University of Hasanuddin, Indonesia. The transfer of materials was overseen by J. Jompa of the University of Hasanuddin and conducted as stated within the Memorandum of Understanding between the University of Hasanuddin and the Leibniz Centre for Tropical Marine Research.

\section{RESULTS}

\section{Benthic Community}

There was a clear grouping of the near-shore sites driven by high turf algae and rubble composition (Table 1, Figure 2). The farthest site, KP, separated from all other groups based on high CCA and live coral cover (Table 1, Figure 2). The second farthest site, KS, separated out because of high cover of sponge and cyanobacteria, and high rugosity. There was, however, a central group consisting of $\mathrm{BA}$ and one replicate of $\mathrm{KS}$ and $\mathrm{BL}$ each (Table 1, Figure 2) which represents intermediate conditions of high coral and CCA, but also high rubble and turf cover.

\section{Padina sp., Turf Algae and Detritus}

Nitrogen $\left(\delta^{15} \mathrm{~N}\right)$ isotopic values of detritus and turf algae were significantly different among sites (Figure 3). Generally, $\delta^{15} \mathrm{~N}$ values were highest near the mainland and decreased with increasing distance from shore. However, the turf algae had its lowest value at $\mathrm{BO}$ (Figure 3 ). The only difference among sites for carbon $\left({ }^{13} \mathrm{C}\right)$ was for detritus (Figure 3) with KP having the highest value (Figure 3). Levene's test indicated a significant difference in variation in only one instance, the $\delta^{15} \mathrm{~N}$ of turf algae (Figure 3). Thus, heteroscedasticity in turf algae values indicates its ANOVA results must be interpreted with caution. Within sites, the $\delta^{15} \mathrm{~N}$ and $\delta^{13} \mathrm{C}$ of the differing foods were always significantly different (Table 2, Figure 3) while the degree of variability was only significant for $\delta^{13} \mathrm{C}$ at $\mathrm{BO}$.

\section{Trophic Niches between Species}

Stable isotopic values for Dischistodus prosopotaenia and Chlorurus bleekeri were largely differentiated based on their $\delta^{13} \mathrm{C}$ 
TABLE 1 | Mean percentage benthic cover ( \pm SE below) of primary biotic and structural groups, and rugosity.

\begin{tabular}{|c|c|c|c|c|c|c|}
\hline Site & SA & BL & BO & BA & KS & KP \\
\hline Distance (km) & 7 & 11 & 14 & 19 & 27 & 55 \\
\hline \multicolumn{7}{|c|}{ BIOTIC GROUPS } \\
\hline \multirow[t]{2}{*}{ Macroalgae } & 1.41 & 0.53 & 4.17 & 1.35 & 0.58 & 1.88 \\
\hline & 0.54 & 0.41 & 0.67 & 0.51 & 0.41 & 0.21 \\
\hline \multirow[t]{2}{*}{ CCA } & 2.79 & 2.95 & 2.53 & 9.24 & 5.05 & 20.15 \\
\hline & 0.66 & 0.16 & 0.45 & 0.68 & 0.54 & 3.41 \\
\hline \multirow[t]{2}{*}{ Sponge } & 1.65 & 4.13 & 6.26 & 4.50 & 16.83 & 4.77 \\
\hline & 0.27 & 0.60 & 1.66 & 0.40 & 9.10 & 0.01 \\
\hline \multirow[t]{2}{*}{ Cyanobacteria } & 0.28 & 0.90 & 5.27 & 1.01 & 19.37 & 0.70 \\
\hline & 0.11 & 0.22 & 0.66 & 0.30 & 6.28 & 0.19 \\
\hline \multirow[t]{2}{*}{ Live coral } & 13.44 & 21.94 & 7.92 & 35.73 & 16.19 & 31.30 \\
\hline & 3.34 & 7.32 & 1.18 & 1.37 & 1.37 & 1.94 \\
\hline \multirow[t]{2}{*}{ Turf algae } & 60.29 & 44.82 & 57.15 & 34.42 & 26.32 & 20.40 \\
\hline & 2.69 & 3.59 & 1.43 & 2.76 & 4.13 & 2.28 \\
\hline \multicolumn{7}{|c|}{ STRUCTURAL GROUPS } \\
\hline \multirow[t]{2}{*}{ Sand } & 7.13 & 13.31 & 10.39 & 3.84 & 4.34 & 9.44 \\
\hline & 1.96 & 1.49 & 2.10 & 1.54 & 4.02 & 0.45 \\
\hline \multirow[t]{2}{*}{ Pavement } & 22.24 & 27.19 & 30.44 & 19.98 & 18.83 & 39.07 \\
\hline & 6.58 & 2.45 & 4.03 & 1.07 & 1.92 & 0.87 \\
\hline \multirow[t]{2}{*}{ Rubble } & 35.59 & 23.84 & 32.89 & 29.85 & 18.65 & 10.87 \\
\hline & 4.33 & 2.86 & 5.76 & 2.26 & 3.55 & 0.86 \\
\hline \multirow[t]{2}{*}{ Rugosity } & 1.57 & 1.91 & 1.65 & 1.98 & 2.19 & 1.70 \\
\hline & 0.09 & 0.15 & 0.11 & 0.12 & 0.04 & 0.15 \\
\hline
\end{tabular}

Sites (SA, Samalona; BL, Barrang Lompo; BO, Bonetambung; BA, Badi; KS, Karang Kassi; KP, Kapoposang) are ordered increasing in distance from the mainland.

values. C. bleekeri ranged in $\delta^{13} \mathrm{C}$ from $-8.5 \%$ o to $-12 \%$ while D. prosopotaenia ranged from $-13 \%$ o to $-16 \%$ (Figures 4,5 ). $\delta^{15} \mathrm{~N}$ values of $D$. prosopotaenia were within the range of the most enriched $C$. bleekeri values, with the former ranging from $5.7 \%$ o to $7.3 \%$ and the latter from $4.3 \%$ o to $7.3 \%$ o (Figures 4,5 ). The stable isotope metrics of $D$. prosopotaenia and C. bleekeri showed that the damselfish trophic niches $\left(\mathrm{SEA}_{\mathrm{c}}\right)$ were approximately half the size of that of the parrotfish (Table 3 ). This was reflected in both the range of resources ( $\delta \mathrm{CR})$ and trophic levels $(\delta \mathrm{NR})$ which were smaller for D. prosopotaenia (Table 3). Concurrently, the damselfish also showed lower CD (trophic diversity) and SDNND (trophic evenness) values than the parrotfish (Table 3). At no point did the trophic niches of the two fishes overlap (Figure 5).

\section{Trophic Niches across Sites}

SIBER indicated no statistical differences among sites in SEAc for either fish, except that BO was significantly smaller than BL and KS for the damselfish $(p<0.05)$. There was, however, a clear increase in the range $(\delta C R)$ in the parrotfish (Table 3), with values increasing from 1.67 to 2.64 between SA and KS. KP had a slightly lower $\delta \mathrm{CR}$ value (2.40) than the next site closer to shore (KS). Mean $\delta^{13} \mathrm{C}$ and $\delta^{15} \mathrm{~N}$ values of the parrotfish were significantly different among sites $\left[\delta^{13} \mathrm{C}\right.$ : Pseudo- $F_{(5,58)}=5.577$,

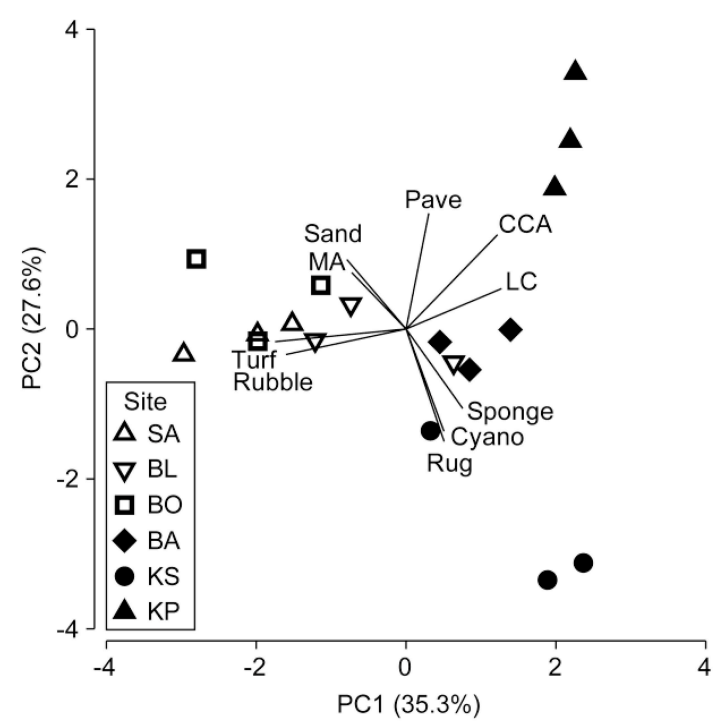

FIGURE 2 | Principal component analysis (PCA) performed on benthic biota, structure and rugosity [macroalgae (MA), crustose coralline algae (CCA), sponge, cyanobacteria (Cyano), live coral (LC), turf algae (Turf), sand, pavement (Pave), rubble and rugosity (Rug); Table 1]. The three sites nearest to shore a (SA, Samalona $7 \mathrm{~km}$; BL, Barrang Lompo $11 \mathrm{~km}$; BO,

Bonetambung $14 \mathrm{~km}$ ) are indicated with open symbols. The three sites further from shore (BA, Badi 19 m; KS, Karang Kassi 27 km; KP, Kapoposang 55 km) are indicated with closed symbols. Vectors indicate direction of separation based on specific benthic characteristics.

$p<0.001 ; \delta^{15} \mathrm{~N}:$ Pseudo- $\left.F_{(5,58)}=9.731, p<0.001\right]$. SA and KS had significantly lower mean $\delta^{13} \mathrm{C}$ values than other sites (Figure 4). A clear pattern was not evident in the $\delta \mathrm{NR}$; however SA samples were enriched in ${ }^{15} \mathrm{~N}$ by $\sim 1 \%$ o compared to the other sites (Figure 4). Samples from SA, BO and BA had the widest $\delta \mathrm{NR}$, while those from the two farthest sites had half that range (Figure 3). There was more overlap of isotopic niche width between sites in the parrotfish than the damselfish (Table 4).

Patterns in Layman's metrics and mean corrected isotope values were less clear for the damselfish. $\delta \mathrm{NR}$ was highest at BA and lowest at BO (Figure 3). Mean $\delta^{13} \mathrm{C}$ and $\delta^{15} \mathrm{~N}$ values were also significantly different among sites for the damselfish $\left[\delta^{13} \mathrm{C}\right.$ : Pseudo- $F_{(5,38)}=3.689, p<0.01 ; \delta^{15} \mathrm{~N}$ : Pseudo- $F_{(5,38)}=4.074$, $p<0.01]$. The low values at $\mathrm{BO}$ were relatively low in $\delta^{15} \mathrm{~N}$ and high in $\delta^{13} \mathrm{C}$ (Figure 5), however this site also had the lowest sample size. $\delta \mathrm{CR}$ was particularly high at $\mathrm{BL}$, but mean $\delta^{13} \mathrm{C}$ values showed few differences among sites (Figure 5).

The relationship between isotopic niche metrics and benthic categories was only significant between $C$. bleekeri and for rubble. Both the $\delta \mathrm{NR}\left(R^{2}=0.89, p<0.05\right)$ and $\operatorname{SEA}_{\mathrm{C}}\left(R^{2}=0.81\right.$, $p<0.05)$ were positively correlated (Figures 6A,C), while the $\delta \mathrm{CR}\left(R^{2}=0.82, p<0.05\right)$ was negatively correlated with rubble (Figure 6B).

\section{DISCUSSION}

Localized disturbances to coral reef ecosystems can involve important alterations to the habitat, and consequently, to the 


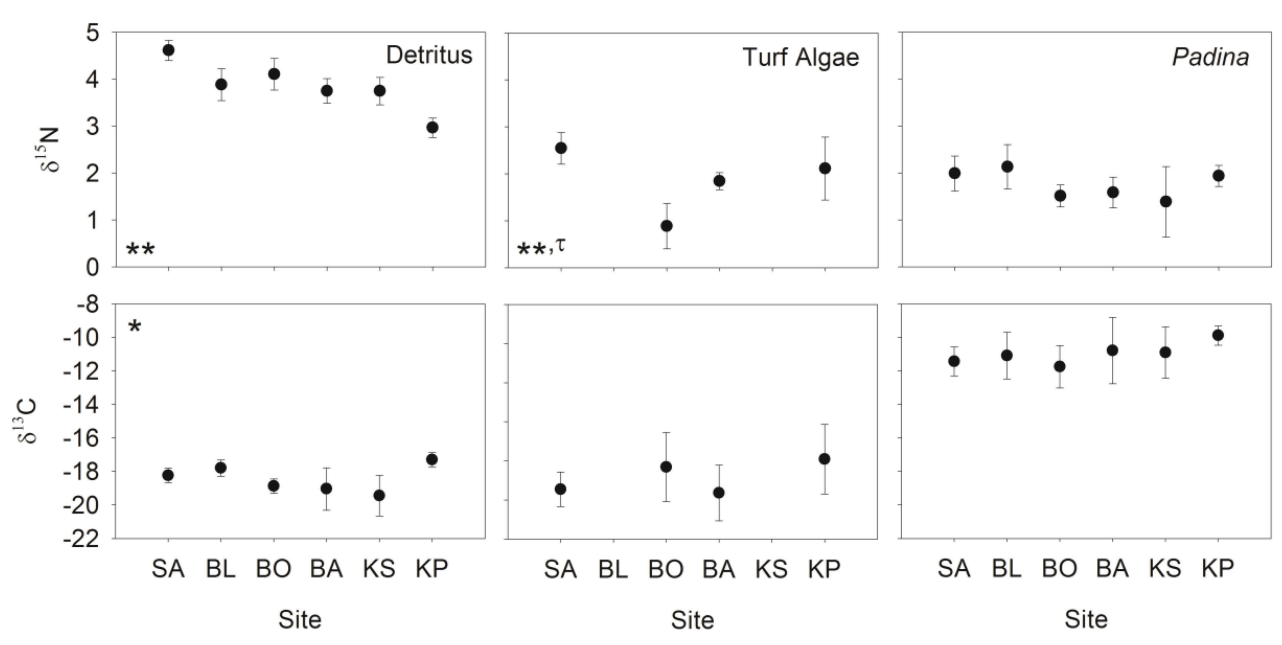

FIGURE 3 | Mean $( \pm \mathrm{SD}) \delta^{13} \mathrm{C}$ and $\delta^{15} \mathrm{~N}$ of detritus, turf algae and Padina. Sites are ordered left to right increasing in distance from the mainland. Asterisks indicate significance level in ANOVA $\left({ }^{*} p<0.01,{ }^{* *} p<0.001\right)$ and tau indicates significance in the Levene's test $(\tau: p<0.05)$.

TABLE 2 | Differences in values (ANOVA) and variance (Levene's test) of food sources within sampling sites.

\begin{tabular}{|c|c|c|c|c|c|c|}
\hline \multirow[t]{2}{*}{ Site } & \multirow[t]{2}{*}{$\delta$} & \multirow[t]{2}{*}{ DF } & \multicolumn{2}{|c|}{ ANOVA } & \multicolumn{2}{|c|}{ Levene's } \\
\hline & & & $\boldsymbol{F}$ & $p$ & $F$ & $p$ \\
\hline \multirow[t]{2}{*}{ SA } & $\mathrm{N}$ & 2.13 & 94.89 & $<0.001^{*}$ & 0.471 & 0.634 \\
\hline & C & & 121.4 & $<0.001^{*}$ & 1.391 & 0.286 \\
\hline \multirow[t]{2}{*}{$\mathrm{BL}$} & $N$ & 1.8 & 45.31 & $<0.001^{*}$ & 1.825 & 0.214 \\
\hline & C & & 104.6 & $<0.001^{*}$ & 7.732 & 0.024 \\
\hline \multirow[t]{2}{*}{ BO } & $\mathrm{N}$ & 2.13 & 108.8 & $<0.001^{*}$ & 3.325 & 0.071 \\
\hline & C & & 39.73 & $<0.001^{*}$ & 8.662 & $0.005^{*}$ \\
\hline \multirow[t]{2}{*}{ BA } & $N$ & 2.13 & 106.3 & $<0.001^{*}$ & 1.437 & 0.273 \\
\hline & C & & 38.72 & $<0.001^{*}$ & 0.811 & 0.467 \\
\hline \multirow[t]{2}{*}{ KS } & $N$ & 1.8 & 19.88 & $<0.001^{*}$ & 0.133 & 0.725 \\
\hline & C & & 39.70 & $<0.001^{*}$ & 0.871 & 0.378 \\
\hline \multirow[t]{2}{*}{$\mathrm{KP}$} & $N$ & 2.13 & 55.32 & $<0.001^{\star}$ & 1.400 & 0.284 \\
\hline & C & & 527.5 & $<0.001^{*}$ & 0.573 & 0.579 \\
\hline
\end{tabular}

A significant $p$-value in either test is represented with an asterisk $\left(^{*}\right)$.

ecological niches of the associated fish communities. Our results agree with previous studies in the Spermonde Archipelago (Edinger et al., 1998, 2000; Sawall et al., 2012; Plass-Johnson et al., 2015a, 2016a,b), where the three sites closer to shore were characterized by low coral cover, higher rubble and higher abundances of turf algae. Cross-shelf variation in these benthic components are related to isotopic metrics of the parrotfish, Chlorurus bleekeri. A positive relationship between rubble and $\mathrm{SEA}_{\mathrm{c}}$ and $\delta \mathrm{NR}$, and a negative relationship with $\delta \mathrm{CR}$ suggest change in resource use and the trophic niche for C. bleekeri while little change in isotopic metrics was observed for the damselfish Dischistodus prosopotaenia.

Given the many sources of variation in isotope values, an increase in $\delta \mathrm{CR}$ of a consumer could be due to the consumption of more food sources across a range of distinct ${ }^{13} \mathrm{C}$ values or it

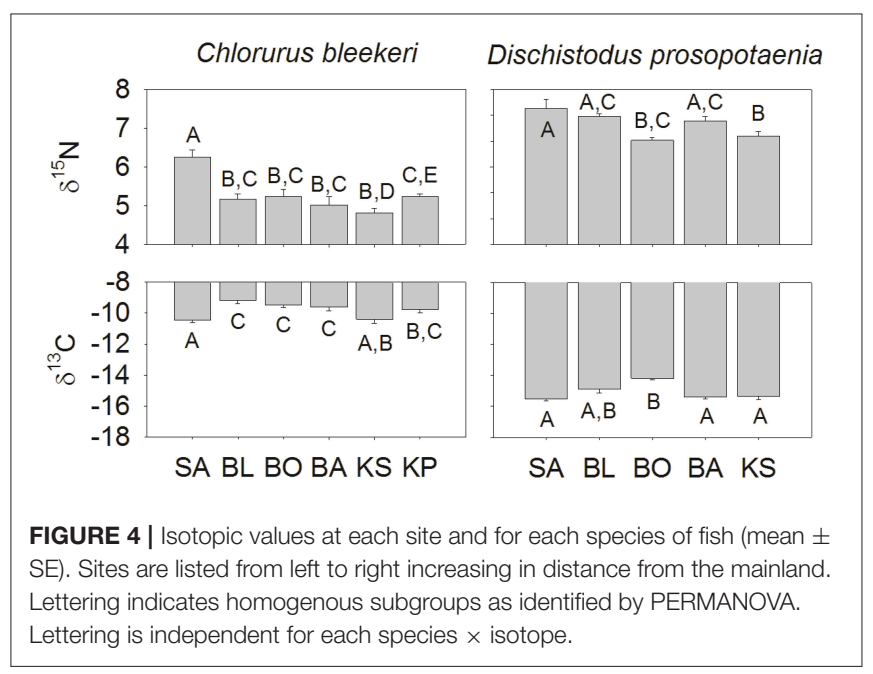

could be due to increasing variation in the ${ }^{13} \mathrm{C}$ values of each of the food sources. Here, we show that the variability in the $\delta^{13} \mathrm{C}$ values of individual food sources (turf algae and detritus) and other benthic constituents (Padina sp.) do not differ significantly among sites. With the exception of $\mathrm{BO}$, these three groups do differ from each other within sites. This among-site similarity within food, and within-site difference among foods, suggests that the increased $\delta \mathrm{CR}$ is most likely a product of an increasingly diverse diet. Further differences in trophic responses of the two fishes are reflected in the size of their trophic niche $\left(\mathrm{SEA}_{\mathrm{c}}\right)$ with D. prosopotaenia's being half the size of C. bleekeri. Smaller SEA $\mathrm{A}_{\mathrm{c}}$, $\delta \mathrm{CR}$ and $\delta \mathrm{NR}$ indicate the damselfish had a much more restricted diet than the parrotfish.

Although parrotfishes are known to feed from turf algae, their diet also includes detritus, endolithic algae and invertebrates (Choat et al., 2002; Plass-Johnson et al., 2013; Dromard et al., 


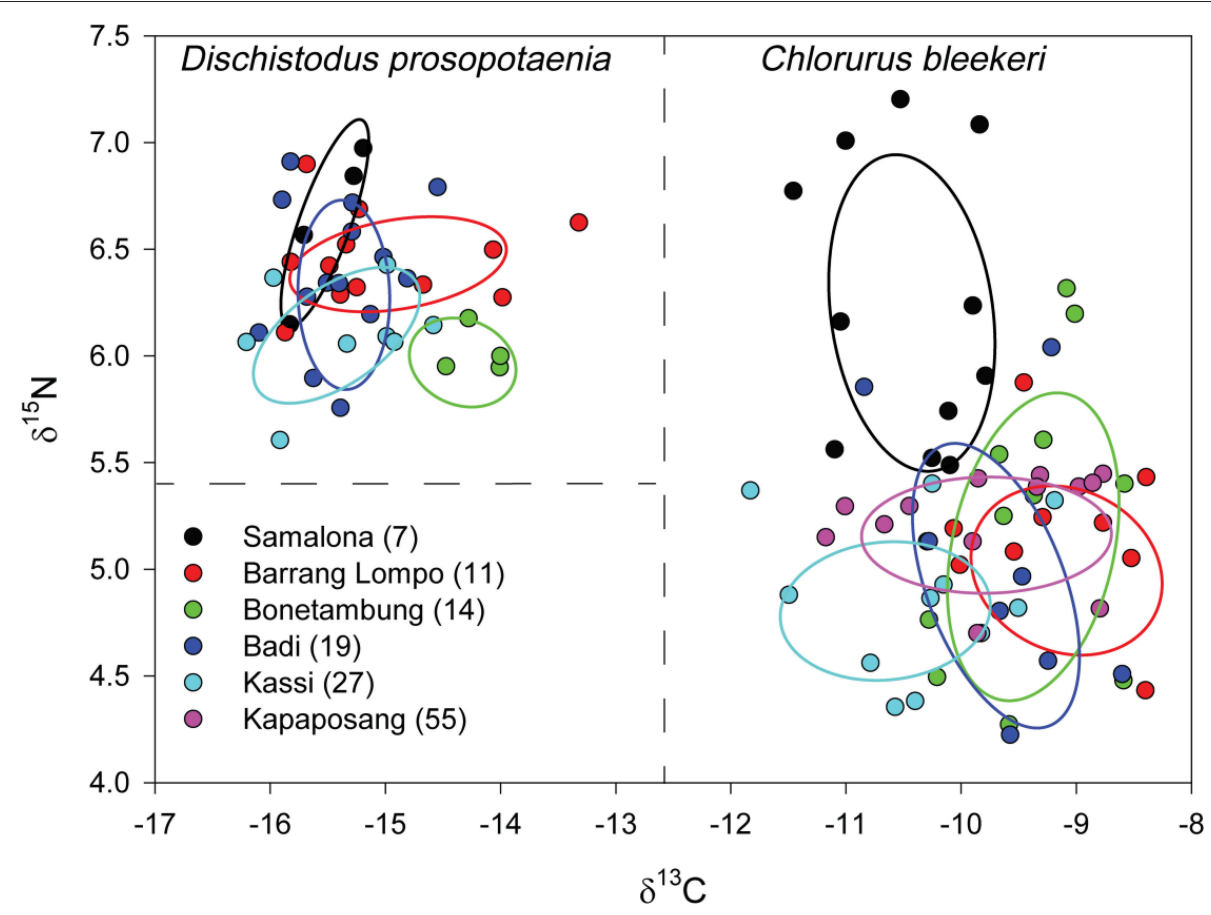

FIGURE $5 \mid \delta^{15} \mathrm{~N}$ and $\delta^{13} \mathrm{C}$ bi-plot of fish values with corrected standard ellipse areas (SEA $\mathrm{C}$ ) representing the core niche space of $C$. bleekeri and $D$. prosopotaenia by site. Dashed lines are a visual aid to identify differing niche areas of the two fish species. Sites are listed in order of increasing distance from Makassar, with distance $(\mathrm{km})$ given in brackets.

TABLE 3 | SIBER and Layman's isotopic niche metrics for both species of herbivorous fishes.

\begin{tabular}{|c|c|c|c|c|c|c|c|c|}
\hline Site & $n$ & Mean length & Length range & $\delta$ NR & $\delta \mathrm{CR}$ & CD & SDNND & $\mathrm{SEA}_{\mathbf{C}}$ \\
\hline \multicolumn{9}{|l|}{ D. prosopotaenia } \\
\hline Samalona (7) & 4 & 8.8 & $6.8-11.4$ & 0.820 & 0.640 & 0.393 & 0.164 & 0.182 \\
\hline Bonetambung (14) & 4 & 11.5 & $10.5-12.5$ & 0.230 & 0.470 & 0.214 & 0.143 & 0.116 \\
\hline Badi (19) & 14 & 15.5 & $13.9-17.0$ & 1.150 & 1.550 & 0.463 & 0.118 & 0.481 \\
\hline Samalona (7) & 11 & 24.9 & 19.8-28.4 & 1.710 & 1.670 & 0.829 & 0.187 & 1.340 \\
\hline Barrang Lompo (11) & 9 & 21.9 & $14.2-27.5$ & 1.440 & 1.670 & 0.665 & 0.174 & 0.878 \\
\hline Bonetambung (14) & 12 & 23.1 & $15.8-28.0$ & 2.050 & 1.710 & 0.764 & 0.249 & 1.262 \\
\hline Badi (19) & 8 & 24.1 & 20.8-30.5 & 1.820 & 2.240 & 0.766 & 0.298 & 1.439 \\
\hline Karang Kassi (27) & 11 & 19.9 & $16.4-24.0$ & 1.050 & 2.640 & 0.713 & 0.187 & 1.012 \\
\hline
\end{tabular}

Species, site with distance $(\mathrm{km})$ from shore, sample size $(\mathrm{n})$, average fish length and length range, and mean stable isotope metrics: $\delta N R, \delta^{15} \mathrm{~N}$ range; $\delta C R, \delta^{13} \mathrm{C}$ range; $C D$, mean distance to centroid; SDNND, standard deviation of nearest neighbor distance; SEAC, standard ellipse area corrected for small sample size.

2014; Clements et al., 2016). Our results indicate that C. bleekeri is assimilating foods with ${ }^{13} \mathrm{C}$ values closer to that of Padina sp. (Figure 5). While the exact food source cannot be determined, the significant relationship between $\delta \mathrm{CR}, \mathrm{SEA}_{\mathrm{C}}, \delta \mathrm{NR}$ and rubble composition suggests that the alternate source may be indirectly linked to rubble. Because C. bleekeri's $\delta \mathrm{CR}$ becomes narrower, its $\delta \mathrm{NR}$ becomes wider, and the $\mathrm{SEA}_{\mathrm{C}}$ gets larger as rubble content increases, it seems that an increase in rubble reduces the number of food sources, but C. bleekeri begins to eat across a broader range of trophic levels. Clements et al. (2016) recently identified parrotfishes as microphages, getting their protein from cyanobacteria and other microorganisms that are (a) living either on or in calcareous substrates, (b) epiphytic on algae or (c) endosymbionts of sessile invertebrates. Nonetheless, the strong relationship between the metrics and rubble indicates that the fish is altering its diet, perhaps toward cyanobacteria 
TABLE 4 | Percentage (\%) of niche area (SEA) overlapping between sites for $C$. bleekeri (gray) and D. prosopotaenia (white).

\begin{tabular}{lcccccc}
\hline & SA & BL & BO & BA & KS & KP \\
\hline SA & & 5 & $0^{*}$ & 11 & $<1$ & NA \\
BL & $<1^{*}$ & & $<1^{*}$ & 25 & 6 & NA \\
BO & $<1$ & 60 & & $0^{*}$ & $0^{*}$ & NA \\
BA & $2^{*}$ & 50 & $87^{*}$ & & 19 & NA \\
KS & $<1^{*}$ & 2 & $24^{*}$ & 34 & & NA \\
KP & $<1^{*}$ & 37 & $48^{*}$ & 54 & 19 & \\
\hline
\end{tabular}

D. prosopotaenia was not collected from Kapoposang (KP). An asterisk $\left(^{*}\right)$ indicates a significate difference in the standard ellipse area (SEA).

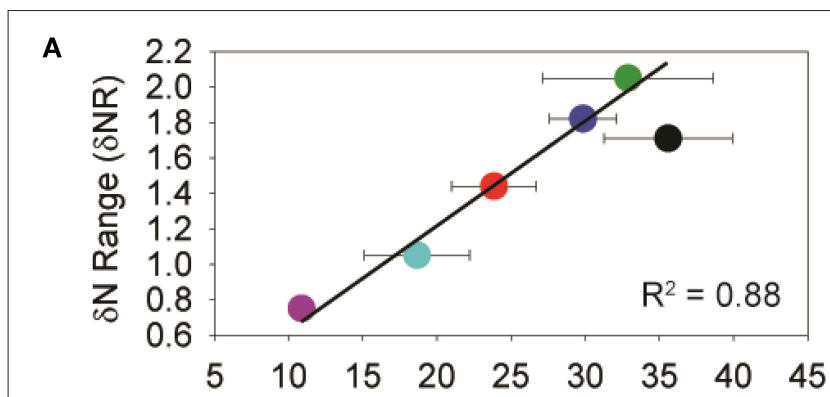

B

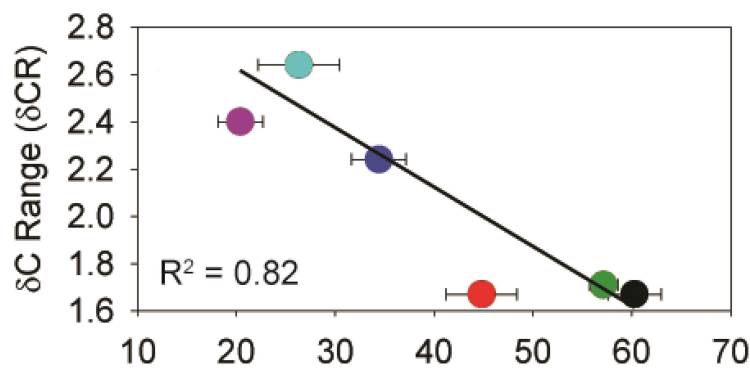

C

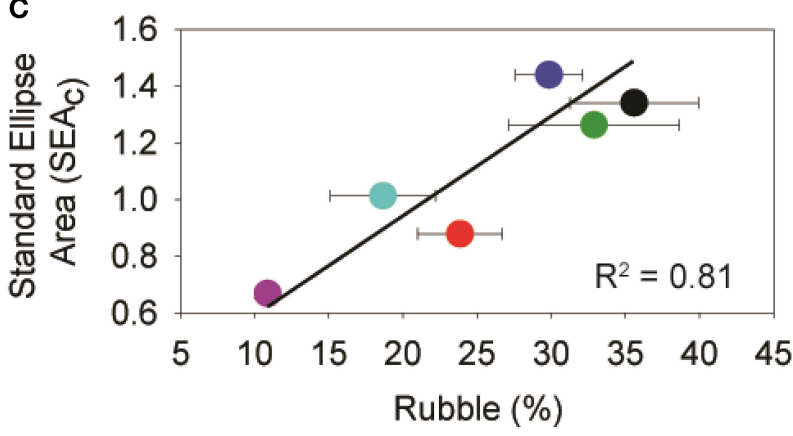

FIGURE 6 | Plots of significant isotopic niche metrics of $C$. bleekeri vs. mean $(\% \pm \mathrm{SE})$ rubble cover. Based on the Pearson Product-Moment Correlation Coefficient, all alpha values were between 0.02 and 0.05 , with 4 degrees of freedom. Colors represent the different sampling sites and correspond to Figures 1, 5 .

and/or microorganisms associated with rubble and away from hard substrate associated biota, suggesting a degree of trophic plasticity based on changes in the habitat structure (Bellwood,
1995; Bonaldo and Bellwood, 2009). Given the reduction in the $\delta \mathrm{CR}$ at SA, it would seem that they become more focused on foods associated with rubble.

In the case of the damselfish, D. prosopotaenia, there was little consistent change in its trophic niche in relation to the environment or distance from shore. Furthermore, there were no significant relationships between benthic components and the Layman's metrics of the damselfish. The farming damselfish feed on their cultivated algae but also on the invertebrate communities and detritus that become established within the algal mat (Wilson and Bellwood, 1997; Dromard et al., 2013), suggesting two possible sources of variability; the invertebrate community and the algae. Recent studies have shown that in the Spermonde Archipelago there is significant variation in invertebrate recruitment in relation to distance from shore (Plass-Johnson et al., 2016a). Undoubtedly variation in invertebrate composition may contribute to some differences in the damselfish values (i.e., BO), however, differences in the species composition of the turf algae among farmed territories may also contribute to variability. Although the sampling for this study attempted to isolate sources of variability in the values of the consumers, further explanation of D. prosopotaenia's trophic niche may need to include a more specific investigation that integrates dietary and behavioral variation (Helfman, 1989).

The mechanisms of species co-existence in highly diverse systems at a small spatial scale are generally maintained via fine-scale niche partitioning by resource specialization (Dobzhansky, 1950). Interestingly, there was never an overlap in the isotopic niche space between the two species at any site. Farming damselfish aggressively defend their territory from other herbivores (Ceccarelli et al., 2005) including parrotfish (Ceccarelli et al., 2011), and the lack of isotopic overlap between D. prosopotaenia over C. bleekeri suggests that the latter may not feed often within the territory of the damselfish. This is further supported by the $\sim 3 \%$ difference between the fishes in their ${ }^{13} \mathrm{C}$ values indicating they may be assimilating completely different foods associated with their diets which is also in line with parrotfishes as microphages (Clements et al., 2016). In nearly every instance however, at any site, the Layman's metrics of the parrotfish were greater than those of the damselfish, likely reflecting their contrasting trophic strategies and also evolutionary history. For instance, the capacity of the parrotfish to forage at greater distances may enable them to target a diversity of resources that is only limited by their home range (Welsh and Bellwood, 2012). While wider foraging ranges may conversely result from reliance on specific, rare resources, their robust jaw morphology (Bellwood, 1994) and a gut able to process high sediment loads (Choat et al., 2002) support the first interpretation, as they allow the fish to process more foods with differing isotopic values. In contrast, farming damselfish actively select the composition of their $1 \mathrm{~m}^{2}$ territories (Hata and Kato, 2004; Ceccarelli et al., 2005) which counterintuitively can also lead to higher diversity via intermediate disurbance (Gochfeld, 2010). Their restricted niche values suggest that they are reduced in the number of food sources that they assimilate in comparison to the parrotfish. As a result, the SEA $\mathrm{C}_{\mathrm{C}}$ values and the isotopic ranges ( $\delta \mathrm{CR}$ and $\delta \mathrm{NR}$ ) of the parrotfish were $\sim 10 \times$ and $\sim 1.5-2 \times$, 
respectively, greater than those of the damselfish. Furthermore, the mean values of the parrotfish were nearly two trophic levels (one trophic level $=3.4 \%$; Post, 2002) higher for ${ }^{15} \mathrm{~N}$ and $2-$ $3 \%$ for ${ }^{13} \mathrm{C}$ than the damselfish. Thus, although $D$. prosopotaenia and C. bleekeri are similar in their diets, morphological and behavioral specialization allow them to occupy distinctive dietary niches while coexisting (Cowman et al., 2009).

The occurrence of local and global disturbance to coral reefs is increasing because of climate change and human resource use (Burke et al., 2011). These disturbances result in modifications of the coral reef habitat, and this will have important effects on the associated fish species. In the worst case scenarios, a coral-dominated reef can transition to macroalgal, sponge or other non-coral dominance (Norström et al., 2009). The maintenance of micro-habitat by $D$. prosopotaenia, a fish that selects specific groups of algae and invertebrates (Hoey and Bellwood, 2010), guarantees resource availability despite a change in the greater environment. In contrast, the ability of $C$. bleekeri to vary resource utilization across differing habitat compositions is a different response allowing persistence in the face of environmental change. The ability to adapt resource utilization according to a changing habitat seems particularly important given that the species may actively avoid some altered coral reef conditions (Hoey and Bellwood, 2011; Welsh and Bellwood, 2015). Understanding species-specific responses to changed habitat will allow to better predict changes in community due to local and global disturbances.

The analysis of stable isotopes in coral reef food webs offers a powerful tool in elucidating trophic variation among consumers (Cocheret de la Moriniere et al., 2003; Carassou et al., 2008; Kolasinski et al., 2009; Greenwood et al., 2010; Dromard et al., 2013, 2014; Plass-Johnson et al., 2013, 2015b), however further clarification of sources of variability is needed to successfully apply this method within highly diverse systems. In our study, turf algae was more abundant at the degraded sites, however, the parrotfish C. bleekeri may have altered its feeding behavior because of specific structural (rubble)

\section{REFERENCES}

Anderson, M., Gorley, R., and Clarke, K. (2008). PERMANOVA+ for PRIMER: Guide to Software and Statistical Methods. Plymouth: Primer-E.

Bay, L. K. (1999). Interactions among the Territorial Behaviour, Spatial Distribution and Habitat Use of Four Congeneric Damselfishes (Dischistodus: Pomacentridae). Hons thesis, James Cook University, 113.

Bearhop, S., Adams, C. E., Waldron, S., Fuller, R. A., and Macleod, H. (2004). Determining trophic niche width: a novel approach using stable isotope analysis. J. Anim. Ecol. 73, 1007-1012. doi: 10.1111/j.0021-8790.2004.00 861.x

Bellwood, D. R. (1994). A phylogenetic study of the parrotfishes family Scaridae (Pisces: Labroidei), with a revision of genera. Rec. Austalian Museum Suppl.20, 1-86. doi: 10.3853/j.0812-7387.20.1994.51

Bellwood, D. R. (1995). Direct estimate of bioerosion by two parrotfish species, Chlorurus gibbus and C. sordidus, on the Great Barrier Reef, Australia. Mar. Biol. 121, 419-429. doi: 10.1007/BF00349451

Bellwood, D. R. D., Hughes, T. T. P., and Hoey, A. S. A. (2006). Sleeping functional group drives coral-reef recovery. Curr. Biol. 16, 2434-2439. doi: 10.1016/j.cub.2006.10.030 preferences for finding foods with ${ }^{13} \mathrm{C}$ values closer to Padina sp. This is further supported by a recent study that identifies cyanobacteria and microorganisms as their target food sources (Clements et al., 2016). Nonetheless, the trophodynamics of parrotfish are still being uncovered (Plass-Johnson et al., 2014; Clements et al., 2016) and the description of the actual feeding capacity of any species will likely take much more work. For parrotfishes, revealing specific diets through isotopes will require the isolation and sampling of endolithic organisms. At the same sites, the farming damselfish $D$. prosopotaenia was able to maintain its trophic niche, suggesting successful defense of its algal community-related resources. These findings help understand both the intra- and inter-specific capacity of two coral reef fishes to change or maintain their trophic relationship within the context of a changing environment. As the effect of environmental degradation on the trophic strategies still remains poorly understood for many species, the current study helps to identify the capacity of some fishes to respond to habitat loss by employing different trophic niches.

\section{AUTHOR CONTRIBUTIONS}

All authors listed, have made substantial, direct and intellectual contribution to the work, and approved it for publication.

\section{FUNDING}

This study was funded by the German Federal Ministry of Education and Research (BMBF; Grant No. 03F0643A) under the bilateral German Indonesian project, Science for the Protection of Indonesian Coastal Ecosystems (SPICE) III.

\section{ACKNOWLEDGMENTS}

We want to thank the University of Hasanuddin for access to the Barrang Lompo research station.

Bonaldo, R., and Bellwood, D. (2009). Dynamics of parrotfish grazing scars. Mar Biol. 156, 771-777. doi: 10.1007/s00227-009-1129-x

Bonaldo, R., Hoey, A., and Bellwood, D. (2014). The ecosystem roles of parrotfishes on tropical reefs. Oceanogr. Mar. Biol. An Annu. Rev. 52, 81-132. doi: 10.1201/b17143-3

Brown, E., Cox, E., Jokiel, P., Rodgers, K., Smith, W., Tissot, B., et al. (2004). Development of benthic sampling methods for the coral reef assessment and monitoring program (CRAMP) in Hawai. Pacific Sci. 58, 145-158. doi: $10.1353 /$ psc. 2004.0013

Burke, L., Reytar, K., Spalding, M., and Perry, A. (2011). Reefs at risk: Revisited. Washington, DC: World Resource Institute. Available online at: http://www. pubmedcentral.nih.gov/articlerender.fcgi?artid=3150666\&tool=pmcentrez\& rendertype $=$ abstract

Carassou, L., Kulbicki, M., Nicola, T., and Polunin, N. (2008). Assessment of fish trophic status and relationships by stable isotope data in the coral reef lagoon of New Caledonia, southwest Pacific. Aquat. Living Resour. 21, 1-12. doi: 10.1051/alr:2008017

Ceccarelli, D. M., Jones, G. P., and McCook, L. J. (2005). Foragers versus farmers: contrasting effects of two behavioural groups of herbivores on coral reefs. Oecologia 145, 445-453. doi: 10.1007/s00442-005-0144-y 
Ceccarelli, D. M., Jones, G. P., and McCook, L. J. (2011). Interactions between herbivorous fish guilds and their influence on algal succession on a coastal coral reef. J. Exp. Mar. Bio. Ecol. 399, 60-67. doi: 10.1016/j.jembe.2011.01.019

Choat, J. H., Clements, K. D., and Robbins, W. D. (2002). The trophic status of herbivorous fishes on coral reefs 1: dietary anaylses. Mar. Biol. 140, 613-623. doi: 10.1007/s00227-001-0715-3

Choat, J. H., Robbins, W. D., and Clements, K. D. (2004). The trophic status of herbivorous fishes on coral reefs II: food processing modes and trophodynamics. Mar. Biol. 145, 445-454. doi: 10.1007/s00227-004-1341-7

Cleary, D., and Renema, W. (2007). Relating species traits of foraminifera to environmental variables in the Spermonde Archipelago, Indonesia. Mar. Ecol. Prog. Ser. 334, 73-82. doi: 10.3354/meps334073

Clements, K. D., German, D. P., Piché, J., Tribollet, A. D., and Howard Choat, J. (2016). Integrating ecological roles and trophic resources on coral reefs: multiple lines of evidence identify parrotfishes as microphages. Biol. J. Linn. Soc. 120, 729-751. doi: 10.1111/bij.12914

Cocheret de la Moriniere, E., Pollux, B. J. A., Nagelkerken, I., Hemminga, M. A., Huiskes, A. H. L., and van der Velde, G. (2003). Ontogenetic dietary changes of coral reef fishes in the mangrove-seagrass-reef continuum: stable isotopes and gut-content analysis. Mar. Ecol. Prog. Ser. 246, 279-289. doi: $10.3354 /$ meps 246279

Cowman, P. F., Bellwood, D. R., and van Herwerden, L. (2009). Dating the evolutionary origins of wrasse lineages (Labridae) and the rise of trophic novelty on coral reefs. Mol. Phylogenet. Evol. 52, 621-631. doi: 10.1016/j.ympev.2009.05.015

Dethier, M., Sosik, E., Galloway, A., Duggins, D., and Simenstad, C. (2013). Addressing assumptions: variation in stable isotopes and fatty acids of marine macrophytes can confound conclusions of food web studies. Mar. Ecol. Prog. Ser. 478, 1-14. doi: 10.3354/meps10310

Dobzhansky, T. (1950). Evolution in the tropics. Am. Sci. 38, 209-221.

Done, T. J. (1992). Phase shifts in coral reef communities and their ecological significance. Hydrobiologia 247, 121-132. doi: 10.1007/BF00008211

Dromard, C. R., Bouchon-Navaro, Y., Cordonnier, S., Fontaine, M. F., Verlaque, M., Harmelin-Vivien, M., et al. (2013). Resource use of two damselfishes, Stegastes planifrons and Stegastes adustus, on Guadeloupean reefs (Lesser Antilles): Inference from stomach content and stable isotope analysis. J. Exp. Mar. Bio. Ecol. 440, 116-125. doi: 10.1016/j.jembe.2012.12.011

Dromard, C. R., Bouchon-Navaro, Y., Harmelin-Vivien, M., and Bouchon, C. (2014). Diversity of trophic niches among herbivorous fishes on a Caribbean reef (Guadeloupe, Lesser Antilles), evidenced by stable isotope and gut content analyses. J. Sea Res. 95, 124-131. doi: 10.1016/j.seares.2014.07.014

Edinger, E., Jompa, J., Limmon, G., Widjatmoko, W., and Risk, M. (1998). Reef degradation and coral biodiversity in Indonesia: effects of land-based pollution, destructive fishing practices and changes over time. Mar. Pollut. Bull. 36, 617-630. doi: 10.1016/S0025-326X(98)00047-2

Edinger, E., Kolasa, J., and Risk, M. (2000). Biogeographic variation in coral species diversity on coral reefs in three regions of Indonesia. Divers. Distrib. 6, 113-127. doi: 10.1046/j.1472-4642.2000.00076.x

English, S., Wilkinson, C., and Baker, V. (1997). Survey Manual for Tropical Marine Resources. Townsville, QLD: Australian Institute of Marine Science.

Fabricius, K., De'ath, G., McCook, L., Turak, E., and Williams, D. M. (2005). Changes in algal, coral and fish assemblages along water quality gradients on the inshore Great Barrier Reef. Mar. Pollut. Bull. 51, 384-398. doi: 10.1016/j.marpolbul.2004.10.041

Fenner, D. (2012). Challenges for managing fisheries on diverse coral reefs. Diversity 4, 105-160. doi: 10.3390/d4010105

Ford, A. K., Eich, A., McAndrews, R. S., Mangubhai, S., Nugues, M. M., Bejarano, S., et al. (2018). Evaluation of coral reef management effectiveness using conventional versus resilience-based metrics. Ecol. Indic. 85, 308-317. doi: 10.1016/j.ecolind.2017.10.002

Glaser, M., Plass-Johnson, J. G., Ferse, S. C. A., Neil, M., Satari, D. Y., Teichberg, M., et al. (2018). Breaking resilience for a sustainable future: thoughts for the anthropocene. Front. Mar. Sci. 5:34. doi: 10.3389/fmars.2018. 00034

Gochfeld, D. J. (2010). Territorial damselfishes facilitate survival of corals by providing an associational defense against predators. Mar. Ecol. Prog. Ser. 398, 137-148. doi: 10.3354/meps08302
Greenwood, N. D. W., Sweeting, C. J., and Polunin, N. V. C. (2010). Elucidating the trophodynamics of four coral reef fishes of the Solomon Islands using $\delta 15 \mathrm{~N}$ and 813 C. Coral Reefs 29, 785-792. doi: 10.1007/s00338-010-0626-1

Harvey, C. J., and Kitchell, J. F. (2000). A stable isotope evaluation of the structure and spatial heterogeneity of a Lake Superior food web. Can. J. Fish. Aquat. Sci. 58, 1395-1403. doi: 10.1139/f00-072

Hata, H., and Kato, M. (2004). Monoculture and mixed-species algal farms on a coral reef are maintained through intensive and extensive management by damselfishes. J. Exp. Mar. Bio. Ecol. 313, 285-296. doi: $10.1016 /$ j.jembe.2004.08.009

Helfman, G. S. (1989). Threat-sensitive predator avoidance in dameselfish-trumpetfish interactions. Behav. Ecol. Sociobiol. 24, 47-58. doi: 10.1007/BF00300117

Hoey, A. S., and Bellwood, D. R. (2010). Damselfish territories as a refuge for macroalgae on coral reefs. Coral Reefs 29, 107-118. doi: 10.1007/s00338-009-0567-8

Hoey, A. S., and Bellwood, D. R. (2011). Suppression of herbivory by macroalgal density: a critical feedback on coral reefs? Ecol. Lett. 14, 267-273. doi: 10.1111/j.1461-0248.2010.01581.x

Hughes, T., Rodrigues, M., Bellwood, D., Ceccarelli, D. M., Hoegh-Guldberg, O., McCook, L., et al. (2007). Phase shifts, herbivory, and the resilience of coral reefs to climate change. Curr. Biol. 17, 360-365. doi: 10.1016/j.cub.2006.12.049

Hutchinson, G. E. (1978). An Introduction to Population Biology. New Haven, CT: Yale University Press.

Jackson, A. L., Inger, R., Parnell, A. C., and Bearhop, S. (2011). Comparing isotopic niche widths among and within communities: SIBER - Stable Isotope Bayesian Ellipses in R. J. Anim. Ecol. 80, 595-602. doi: 10.1111/j.1365-2656.2011.01 806.x

Jackson, M. C., and Britton, J. R. (2013). Variation in the trophic overlap of invasive Pseudorasbora parva and sympatric cyprinid fishes. Ecol. Freshw. Fish 22, 654-657. doi: 10.1111/eff.12063

Jackson, M. C., Donohue, I., Jackson, A. L., Britton, J. R., Harper, D. M., and Grey, J. (2012). Population-level metrics of trophic structure based on stable isotopes and their application to invasion ecology. PLoS ONE 7:e31757. doi: 10.1371/journal.pone.0031757

Jennings, S., Grandcourt, E. M., and Polunin, N. V. C. (1995). The effects of fishing on the diversity, biomass and trophic structure of Seychelles' reef fish communities. Coral Reefs 14, 225-235. doi: 10.1007/BF00334346

Jompa, J., and McCook, L. J. (2003). Contrasting effects of turf algae on corals: massive Porites spp. are unaffected by mixed-species turfs, but killed by the red alga Anotrichium tenue. Mar. Ecol. Prog. Ser. 258, 79-86. doi: $10.3354 /$ meps 258079

Jones, G. P., and Syms, C. (1998). Disturbance, habitat structure and the ecology of fishes on coral reefs. Austral Ecol. 23, 287-297. doi: 10.1111/j.1442-9993.1998.tb00733.x

Kohler, K., and Gill, S. (2006). Coral Point Count with Excel extensions (CPCe): a visual basic program for the determination of coral and substrate coverage using random point count methodology. Comput. Geosci. 32, 1259-1269. doi: 10.1016/j.cageo.2005.11.009

Kolasinski, J., Frouin, P., Sallon, A., Rogers, K., Bruggemann, H., and Potier, M. (2009). Feeding ecology and ontogenetic dietary shift of yellowstripe goatfish Mulloidichthys flavolineatus (Mullidae) at Reunion Island, SW Indian Ocean. Mar. Ecol. Prog. Ser. 386, 181-195. doi: 10.3354/meps08081

Layman, C. A., Arrington, D. A., Montaña, C. G., and Post, D. M. (2007). Can stable isotope ratios provide for community-wide measures of trophic structure? Ecology 88, 42-48. doi: 10.1890/0012-9658(2007)88[42:CSIRPF]2.0. $\mathrm{CO} ; 2$

Ledlie, M., Graham, N., Bythell, J., Wilson, S., Jennings, S., Polunin, N., et al. (2007). Phase shifts and the role of herbivory in the resilience of coral reefs. Coral Reefs 26, 641-653. doi: 10.1007/s00338-007-0230-1

Letourneur, Y., Lison de Loma, T., Richard, P., Harmelin-Vivien, M. L., Cresson, P., Banaru, D., et al. (2013). Identifying carbon sources and trophic position of coral reef fishes using diet and stable isotope ( $\delta 15 \mathrm{~N}$ and $\delta 13 \mathrm{C}$ ) analyses in two contrasted bays in Moorea, French Polynesia. Coral Reefs 32, 1091-1102. doi: 10.1007/s00338-013-1073-6

Lirman, D., and Fong, P. (2007). Is proximity to land-based sources of coral stressors an appropriate measure of risk to coral reefs? An 
example from the Florida Reef Tract. Mar. Pollut. Bull. 54, 779-791. doi: 10.1016/j.marpolbul.2006.12.014

Mallela, J., Perry, C. T., and Haley, M. P. (2004). Reef morphology and community structure along a fluvial gradient, Rio Bueno, Jamaica. Caribb. J. Sci. 40, 299-311.

Newsome, S. D., del Rio Martinez, C., Bearhop, S., and Phillips, D. L. (2007). A niche for isotope ecology. Front. Ecol. Environ. 5, 429-436. doi: 10.1890/060150.1

Norström, A., Nyström, M., Lokrantz, J., and Folke, C. (2009). Alternative states on coral reefs: beyond coral-macroalgal phase shifts. Mar. Ecol. Prog. Ser. 376, 295-306. doi: 10.3354/meps07815

Parnell, A. C., and Jackson, A. L. (2013). SIAR: Stable Isotope Analysis in R. Available online at: http://cran.r-project.org/package=siar

Plass-Johnson, J. G., Teichberg, M., Bednarz, V. N., Gärdes, A., Heiden, J. P., Lukman, M., et al. (2018). Spatio-temporal patterns in the coral reef communities of the spermonde archipelago, 2012-2014, II: fish assemblages display structured variation related to benthic condition. Front. Mar. Sci. 5:36. doi: $10.3389 /$ fmars.2018.00036

Plass-Johnson, J. G., Ferse, S. C., Jompa, J., Wild, C., and Teichberg, M. (2015a). Fish herbivory as key ecological function in a heavily degraded coral reef system. Limnol. Oceanogr. 60, 1382-1391. doi: 10.1002/lno.10105

Plass-Johnson, J. G., Ferse, S. C., Wild, C., and Teichberg, M. (2014). Observation of macroalgal browsing in juvenile humphead parrotfish, Bolbometopon muricatum, in the Spermonde Archipelago, Indonesia. Bull. Mar. Sci. 90, 763-764. doi: 10.5343/bms.2014.1006

Plass-Johnson, J. G., Heiden, J. P., Abu, N., Lukman, M., and Teichberg, M. (2016a). Experimental analysis of the effects of consumer exclusion on recruitment and succession of a coral reef system along a water quality gradient in the Spermonde Archipelago, Indonesia. Coral Reefs 35, 229-243. doi: 10.1007/s00338-015-1369-9

Plass-Johnson, J. G., McQuaid, C. D., and Hill, J. M. (2013). Stable isotope analysis indicates a lack of inter- and intra-specific dietary redundancy among ecologically important coral reef fishes. Coral Reefs 32, 429-440. doi: 10.1007/s00338-012-0988-7

Plass-Johnson, J. G., McQuaid, C. D., and Hill, J. M. (2015b). The effects of tissue type and body size on $\delta 13 \mathrm{C}$ and $\delta 15 \mathrm{~N}$ values in parrotfish (Labridae) from Zanzibar, Tanzania. J. Appl. Ichthyol. 31, 633-637. doi: 10.1111/jai.12746

Plass-Johnson, J. G., Taylor, M. H., Husain, A. A. A., Teichberg, M. C., and Ferse, S. C. A. (2016b). Non-random variability in functional composition of coral reef fish communities along an environmental gradient. PLoS ONE 11:e0154014. doi: 10.1371 /journal.pone.0154014.

Post, D. (2002). Using stable isotopes to estimate trophic position: models, methods, and assumptions. Ecology 83, 703-718. doi: 10.1890/00129658(2002)083[0703:USITET]2.0.CO;2

R Core Team (2015). R: A Language and Environment for Statistical Computing. Vienna: R Foundation for Statistical Computing. Available online at: https:// www.R-project.org/
Risk, M. (1972). Fish diversity on a coral reef in the Virgin Islands. Atoll Res. Bull. 153, 1-6. doi: 10.5479/si.00775630.153.1

Risk, M. J., Lapointe, B. E., Sherwood, O. A., and Bedford, B. J. (2009). The use of $\delta 15 \mathrm{~N}$ in assessing sewage stress on coral reefs. Mar. Pollut. Bull. 58, 793-802. doi: 10.1016/j.marpolbul.2009. 02.008

Sawall, Y., Richter, C., and Ramette, A. (2012). Effects of eutrophication, seasonality and macrofouling on the diversity of bacterial biofilms in equatorial coral reefs. PLoS ONE 7:e39951. doi: 10.1371/journal.pone.00 39951

Smith, J. E., Brainard, R., Carter, A., Dugas, S., Edwards, C., Harris, J., et al. (2016). Re-evaluating the health of coral reef communities: baselines and evidence for human impacts across the central Pacific. Proc. R. Soc. B Biol. Sci. 283, 20151985. doi: $10.1098 / \mathrm{rspb} .2015 .1985$

Syms, C., and Jones, G. (2000). Disturbance, habitat structure, and the dynamics of a coral-reef fish community. Ecology 81, 2714-2729. doi: 10.1890/00129658(2000)081[2714:DHSATD]2.0.CO;2

Teichberg, M., Wild, C., Bednarz, V. N., Kegler, H. F., Lukman, M., Gärdes, A. A., et al. (2018) Spatio-temporal patterns in coral reef communities of the spermonde archipelago, 2012-2014, I: comprehensive reef monitoring of water and benthic indicators reflect changes in reef health. Front. Mar. Sci. 5:33. doi: $10.3389 /$ fmars.2018.00033

Vermeij, M. J., Dailer, M. L., Walsh, S. M., Donovan, M. K., and Smith, C. M. (2010). The effects of trophic interactions and spatial competition on algal community composition on Hawaiian coral reefs. Mar. Ecol. 31, 291-299. doi: 10.1111/j.1439-0485.2009.00343.x

Welsh, J. Q., and Bellwood, D. R. (2012). Spatial ecology of the steephead parrotfish (Chlorurus microrhinos): an evaluation using acoustic telemetry. Coral Reefs 31, 55-65. doi: 10.1007/s00338-011-0813-8

Welsh, J. Q., and Bellwood, D. R. (2015). Simulated macro-algal outbreak triggers a large-scale response on coral reefs. PLoS ONE 10:e0132895. doi: 10.1371/journal.pone.0132895

Wilson, S., and Bellwood, D. R. (1997). Cryptic dietary components of territorial damselfishes (Pomacentridae, Labroidei). Mar. Ecol. Prog. Ser. 153, 299-310. doi: $10.3354 /$ meps 153299

Conflict of Interest Statement: The authors declare that the research was conducted in the absence of any commercial or financial relationships that could be construed as a potential conflict of interest.

Copyright (C) 2018 Plass-Johnson, Bednarz, Hill, Jompa, Ferse and Teichberg. This is an open-access article distributed under the terms of the Creative Commons Attribution License (CC BY). The use, distribution or reproduction in other forums is permitted, provided the original author(s) and the copyright owner are credited and that the original publication in this journal is cited, in accordance with accepted academic practice. No use, distribution or reproduction is permitted which does not comply with these terms. 